\title{
The amino acid requirements of the preruminant calf
}

\author{
By A. P. WILLIAMS AND D. HEWITT \\ National Institute for Research in Dairying, Shinfield, Reading RG2 $9 A T$
}

(Received 25 May 1978-Accepted 4 August 1978)

\begin{abstract}
I. Ten calves (50-58 kg live weight) were given a diet consisting of diluted whole milk, wheat gluten and supplemented with appropriate nutrients including amino acids but deficient in lysine. The lysine requirements of these calves, which were growing at approximately $0.25 \mathrm{~kg} / \mathrm{d}$, were estimated from responses to lysine supplementation of this diet. From plasma urea, plasma lysine, nitrogen retention and apparent digestibility of $\mathrm{N}$ responses the estimated lysine requirements were $8 \cdot 5,7 \cdot 5,7 \cdot 2$ and $7.6 \mathrm{~g} / \mathrm{d}$ respectively.

2. From the mean lysine requirement $(7.8 \mathrm{~g} / \mathrm{d})$ and the ratio, lysine : other essential amino acids in carcasses of similar calves the estimated requirements were $(\mathrm{g} / \mathrm{d})$ : methionine $2 \cdot \mathrm{I}$, cystine $\mathrm{I} \cdot 6$, threonine $4 \cdot 9$, valine 4.8 , isoleucine 3.4 , leucine 8.4 , tyrosine $3 \cdot 0$, phenylalanine 4.4 , histidine 3.0 , arginine $8 \cdot 5$, tryptophan $1 \cdot 0$.
\end{abstract}

The replacement of milk protein by alternative sources of protein in the diet of the preruminant calf is of considerable practical importance but such diets may not meet the amino acid requirements of the calf (Roy et al. 1977). Apart from the recent studies of PatureauMirand et al. (1973a,b), Bouchard \& Brisson (1974), Williams \& Smith (1975) and PatureauMirand et al. (1976) on the lysine and sulphur amino acid (SAA) requirements of the preruminant calf there have been only limited attempts (Patureau-Mirand et al. 1974; Foldager et al. 1977) to assess the requirements for the other essential amino acids (EAA). The wide range of results from these studies suggests the need for further research. In the present paper changes in plasma amino acid (PAA) and plasma urea (PU) concentrations and in growth rate and nitrogen-balance, in response to lysine supplementation of a lysinedeficient diet, were measured to assess the lysine requirements of the preruminant calf. From the lysine requirement estimates of the requirements for the other EAA were made from the ratio EAA : lysine in the body of the preruminant calf (Williams, 1978) by the carcass analysis method of Williams et al. (1954).

\section{EXPERIMENTAL \\ Animals and feeding}

A total of ten Friesian bull calves, aged between 6 and I 4 weeks and weighing from $50-58 \mathrm{~kg}$, was used. All newborn calves were reared for $2 \mathrm{~d}$ on colostrum and thereafter on a wholemilk diet, the pre-experimental diet, given at a rate (approximately $0.05 \mathrm{~kg} / \mathrm{kg}$ live weight) sufficient to maintain an increase in body-weight of approximately $0.25 \mathrm{~kg} / \mathrm{d}$ (Roy et al. 1958). The milk given to calves over 3 weeks of age was supplemented with iron, manganese, copper, magnesium, retinol, $\alpha$-tocopherol and cholecalciferol (Coombe \& Smith, 1973).

Lysine requirements. From approximately $50 \mathrm{~kg}$ live weight the calves were given, for periods of $\mathrm{IO}$ d, diets in random order as described later (see p. 3I 2). The synthetic diets with supplements of $0,1 \cdot 5,3 \cdot 0,4 \cdot 5,6 \cdot 0$ or $7.5 \mathrm{~g}$ L-lysine/d were given in equal amounts twice daily at $\mathrm{I} 0.00$ and 17.00 hours in amounts (approximately $0.05 \mathrm{~kg} / \mathrm{kg}$ live weight) sufficient to maintain an increase in body-weight of approximately $0.25 \mathrm{~kg} / \mathrm{d}$ (Roy et al. 1958). The synthetic diet contained $(/ \mathrm{kg}): 250 \mathrm{~g}$ whole milk, $530 \mathrm{~g}$ synthetic milk similar to that described by Smith (I959) except that $33.8 \mathrm{~g}$ wheat gluten (Rank, Hovis \& McDougall Foods $\mathrm{Ltd}$, Ashford, Kent) was substituted for the casein, and $210 \mathrm{ml}$ of an aqueous solution 
containing the following amino acids $(\mathrm{g})$ : threonine 0.39 , valine 0.54 , methionine 0.23 , isoleucine 0.42 , leucine $0 \cdot 49$, histidine $0 \cdot 10$, tryptophan $0 \cdot 1$ I , glutamine $1 \cdot 70$. Glutamine was decreased with increasing lysine to maintain equal $\mathrm{N}$ in all diets. The composition of the synthetic diet was designed to simulate the composition of cow's milk except for lysine. Since the cystine content of wheat gluten is approximately double that of milk the total SAA content of this diet was in excess of requirements (Williams \& Smith, 1975). Other EAA are considered (Robert, I97 I ; Patureau-Mirand et al. I974) to be present in adequate quantities in cow's milk. Whole milk was included to retain some of the clotting characteristics. To each synthetic diet, mineral solutions A, B and C (Coombe \& Smith, I973) were added at levels of 24,42 and $22 \mathrm{ml} / \mathrm{kg}$ diet respectively. The amino acid, milk and mineral components of the synthetic diets were mixed just before feeding and the whole mixture homogenized for 5 min using a Silverson homogenizer (Model AX; Silverson Machines, London SEI). Amino acids were obtained from SAS Scientific Chemicals Ltd, London and the L-forms were used throughout.

\section{Sampling of blood}

Jugular blood samples were taken from each calf at 13.00 hours on the last day of each period by the procedure described by Williams \& Smith (1975).

\section{Determination of $N$ balance}

$\mathrm{N}$ retention and apparent digestibility of $\mathrm{N}$ were determined by the technique described by Barber et al. (I97I) for 20-60 kg pigs. Urine, faeces and hair were collected daily on the last $5 \mathrm{~d}$ of each experimental period. The calves were weighed at the start and finish of each $5 \mathrm{~d}$ collection period.

\section{Analytical methods}

The total $\mathrm{N}$ in milk, wheat gluten, faeces, urine and hair was determined by a microKjeldahl method (Smith \& McAllan, 1970). Amino acids in milk, wheat gluten and plasma and urea- $\mathrm{N}$ in plasma were determined by the methods described by Williams \& Smith (1975).

\section{Experimental design and statistical analysis}

A balanced incomplete block design was used (Type III; Cochran \& Cox (1957)). Ten calves formed the blocks and each calf received three of the six diets in random order. Each diet was given to five calves. The statistical analysis was as described by Cochran \& Cox (I957) and treatment means, adjusted for calf effects, are presented.

The lysine requirement was assessed in two ways. First, two straight lines were fitted to the values to relate response to dietary intake. One line was restricted to diets that appeared to be deficient and the other to diets that were deemed to be adequate. The lysine intake at the intersection of these lines was taken to be the requirement. The second approach involved fitting quadratic relationships to the values and identifying the ranges of lysine intake that were associated with small and large changes in response. The requirement was taken to be the intake between these ranges.

\section{RESULTS}

The effects of the addition of lysine to the lysine-deficient diet on live-weight gain (LWG), N retention, apparent digestibility of $\mathrm{N}(\mathrm{ADN})$, plasma lysine and plasma urea are given in Table I. Initially each increase in the level of dietary lysine led to a marked increase in LWG, $\mathrm{N}$ retention and $A D N$, but at the highest levels of supplementary lysine there was little change in response except for ADN which decreased. Increasing the levels of dietary lysine led to a marked decrease in PU concentrations when the supplements were small but showed little response to increasing amounts of supplementary lysine when the supplements were 


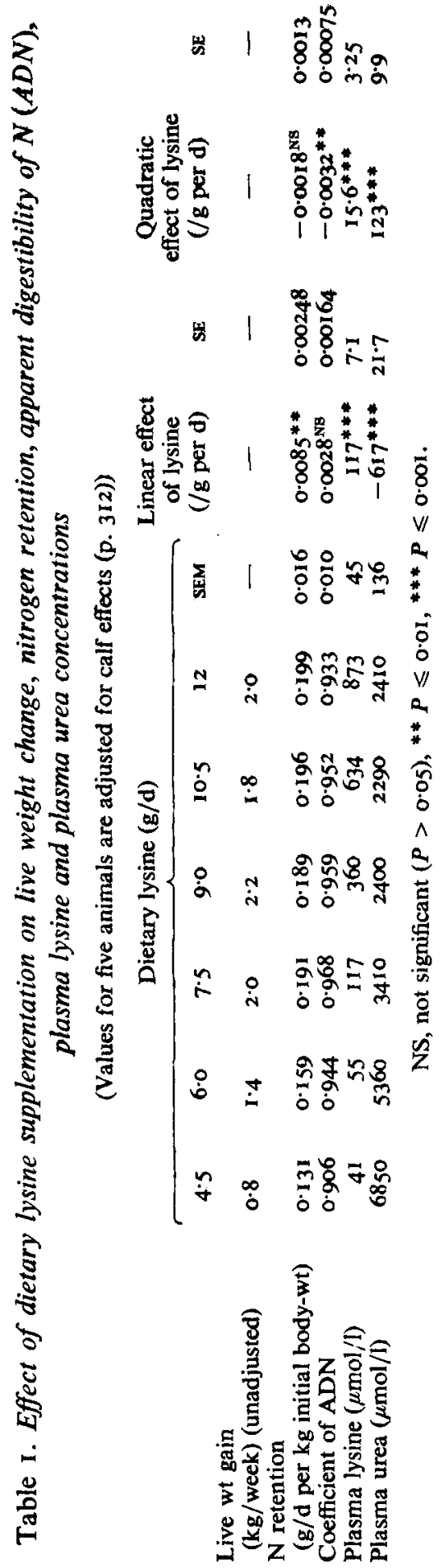



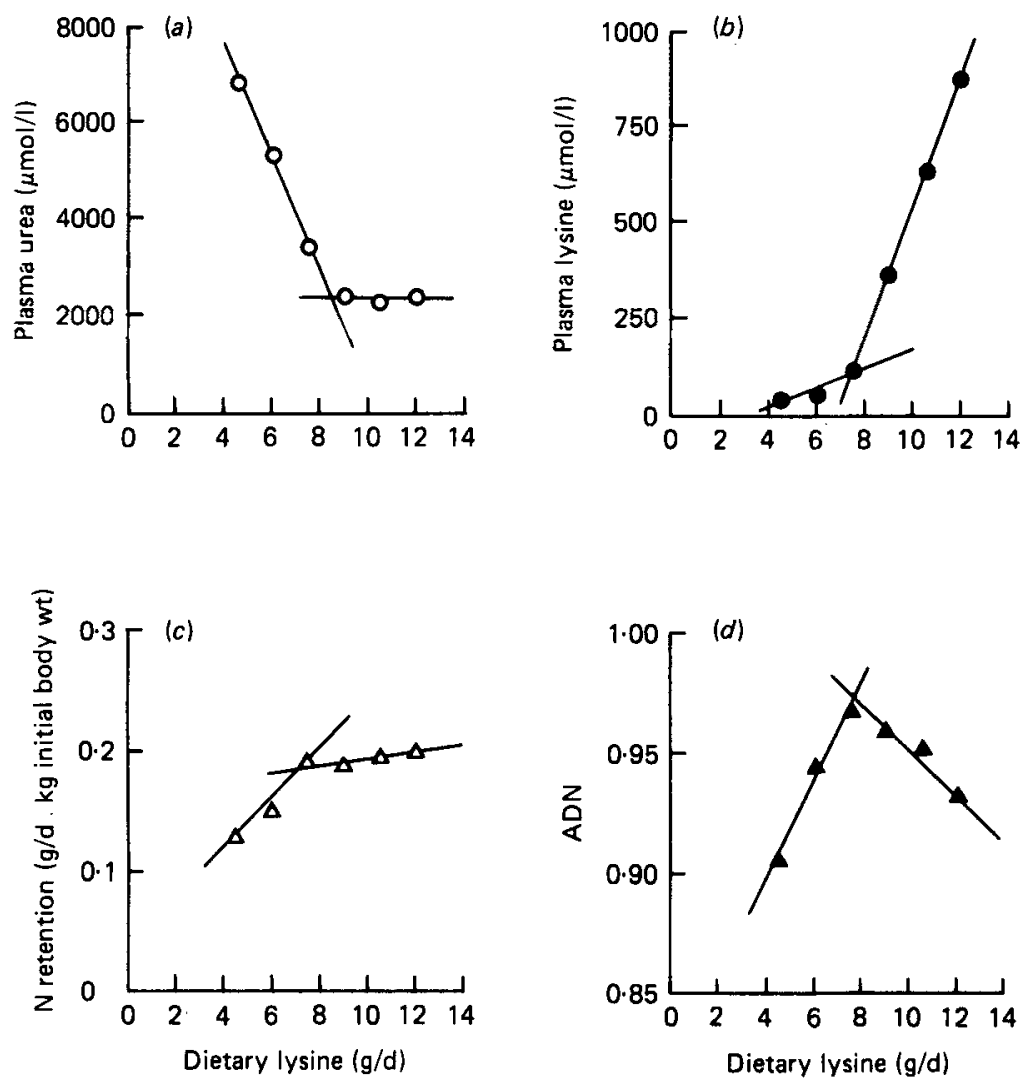

Fig. I. Effect of dietary lysine supplementation on (a) plasma urea ( $\mu \mathrm{mol} / \mathrm{l}),(b)$ plasma lysine $(\mu \mathrm{mol} / \mathrm{l}),(c)$ nitrogen retention $(\mathrm{g} / \mathrm{d}$ per $\mathrm{kg}$ body-weight) and $(d)$ apparent digestibility of $\mathrm{N}(\mathrm{ADN})$ in the calf. (Mean values for five animals.)

large. Increasing dietary lysine supplements had little effect on plasma lysine when the supplements were small but caused plasma lysine to increase markedly when the supplements were large.

Lysine requirements. The results for each measurement are plotted $v$. lysine intake in Fig. I. The linear relationships for points above and below the requirement are given on the figures and the lysine levels corresponding to the points of intersection (taken to estimate lysine requirement) are given in Table 2. Quadratic relationships also fitted the values satisfactorily as indicated by the linear and quadratic effects given in Table I. Plots (not presented here) of these quadratic relationships were also used to assess requirements (given in Table 2) as indicated later.

The responses of $\mathrm{N}$ retention and ADN to dietary lysine supplementation would be represented as two straight lines one increasing and the other horizontal or decreasing (Fig. I $c, d$ ). These indicated requirements of 7.2 and $7.6 \mathrm{~g} / \mathrm{d}$ respectively but in both instances the relationships were not significant and so confidence limits could not be calculated. The levels of lysine above which there was little further change in response according to the quadratic curves were 8-9 and 7-8 g/d respectively. ADN did decrease however at the uppermost level of lysine intake. LWG showed a similar response to $\mathbf{N}$ retention and $A D N$ but any lysine requirement based on it was considered to be unreliable due to the limited variation in the values. The calves were weighed to the nearest $\mathrm{kg}$ and 
Table 2. Comparison of lysine requirements $(g / d)$ for the preruminant calf either calculated from the intersection of linear regression lines (a) or subjectively assessed, from fitted quadratic relationships $(b)$

(a)

Plasma urea
Plasma lysine
Nitrogen retention
ADN
Growth

$\begin{array}{ll}8.5(7 \cdot 9,9 \cdot 4) \dagger & 8-9 \\ 7 \cdot 5(3 \cdot 2,8 \cdot 6) & 6-7 \\ 7 \cdot 2 & 8-9 \\ 7.6 & 7-8 \\ 8 . I^{*} & \text { nd }\end{array}$

nd, Not determined; ADN, apparent digestibility of $\mathrm{N}$.

* Based on unadjusted values.

$\dagger 95 \%$ confidence interval; interval indeterminate for $\mathrm{N}$ retention and ADN.

individual weight gains only ranged from o to $3 \mathrm{~kg}$. A contributory reason for the large animal variation is the difficulty of measuring accurately such a low growth rate $(0.25 \mathrm{~kg} / \mathrm{d})$ in an animal as large as a $50-58 \mathrm{~kg}$ calf. A lysine requirement based on LWG was estimated from the intersection of linear regression lines (Table 2) but it was excluded from calculation of the mean lysine requirement.

PAA response curves have also been used to determine amino acid requirements (Zimmerman \& Scott, I965; Lewis \& Speer, I973; Brown \& Cline, I974) by using the fact that with increasing dietary supplementation with the limiting amino acid its plasma concentration remains at a low, relatively constant level until the requirement is met, after which it increases rapidly. In the present study this type of response was observed for plasma lysine (Fig. $\mathrm{I} b$ ). The point of intersection of these two different types of response indicated a lysine requirement of $7.5 \mathrm{~g} / \mathrm{d}$. The lysine requirement estimated from the fitted quadratic relationship as the intake above which there were large increases in response was $6-7 \mathrm{~g} / \mathrm{d}$ (Table 2). Total plasma EAA (excluding lysine) concentrations decreased as the dietary lysine level increased indicating improved amino acid utilization (Lewis \& Speer, 1973; Chi \& Speers, 1977) but a two-phase response like that for plasma lysine was not observed.

PU response curves have been used to determine amino acid requirements in several species (Lewis \& Speer, 1973 ; Kirk \& Walker, $1976 a, b$ ) by using the fact that as the dietary amino acid balance is improved by supplementation with the limiting amino acid, protein synthesis is increased, less non-limiting amino acids are catabolized and the amount of urea, the primary end-product of amino acid catabolism, in plasma is decreased. When the requirement for the limiting amino acid is met PU remains at a low, relatively constant level. In the present study this type of two-phase response was observed for PU (Fig. I a) with an intersection at $8.5 \mathrm{~g}$ lysine/d (Table 2). The quadratic relationship was treated in the same way as that for $\mathrm{N}$ retention. There was little change in $\mathrm{PU}$ when dietary lysine was increased above 8-9 g/d (Table 2).

Essential amino acid requirements. In growing animals, if the requirement for one amino acid such as lysine with no known function other than for the synthesis of tissue protein is known, then the requirement for the other EAA may be estimated from the ratio, EAA: lysine in the body (Mitchell, I950; Williams et al. 1954). The EAA composition of the bodies of similar preruminant calves to those used in the present study was determined in a separate experiment (Williams, 1978). The requirements estimated from a mean lysine requirement of $7.8 \mathrm{~g} / \mathrm{d}$ are given in Table 3 . It is recognized that this procedure cannot give precise values for reasons discussed more fully later. 
Table 3. Comparison of the estimated EAA requirements $(\mathrm{g} / \mathrm{d})$ of calves $(50-58 \mathrm{~kg}$ live wt) growing at approximately $0.25 \mathrm{~kg} / d$ with the quantities $(\mathrm{g} / \mathrm{d})$ of $E A A$ in cow's milk and unsupplemented milk-substitute diets $\dagger$

\begin{tabular}{|c|c|c|c|c|}
\hline \multirow[b]{2}{*}{ EAA } & \multirow[b]{2}{*}{$\begin{array}{c}\text { Estimated } \\
\text { Requirements* }\end{array}$} & \multicolumn{3}{|c|}{ Diets $(\mathrm{g} / \mathrm{kg} \mathrm{CP})$} \\
\hline & & Cow's milk & $\begin{array}{c}500 \text { Cow's milk } \\
\text { protein } \\
500 \text { isolated } \\
\text { soya-bean protein }\end{array}$ & $\begin{array}{l}250 \text { Cow's milk } \\
\text { protein } \\
750 \text { wheat gluten }\end{array}$ \\
\hline Lysine & $7 \cdot 8$ & I I $\cdot 7$ & $10 \cdot 0$ & 4.5 \\
\hline Methionine & $2 \cdot 1$ & $3 \cdot 6$ & $2 \cdot 8$ & $2 \cdot 6$ \\
\hline Cystine & $1 \cdot 6$ & I'I & $I \cdot 4$ & $2 \cdot 4$ \\
\hline Threonine & 49 & $6 \cdot 4$ & $6 \cdot 2$ & $4 \cdot 7$ \\
\hline Valine & 4.8 & $9 \cdot 2$ & $9 \cdot 4$ & $6 \cdot 9$ \\
\hline Isoleucine & $3 \cdot 4$ & $8 \cdot 2$ & $7 \cdot 8$ & $6 \cdot 4$ \\
\hline Leucine & $8 \cdot 4$ & $13 \cdot 6$ & 13.0 & $11 \cdot 5$ \\
\hline Tyrosine & $3 \cdot 0$ & $7 \cdot 1$ & 7.6 & 5.6 \\
\hline Phenylalanine & $4 \cdot 4$ & $6 \cdot 8$ & $7 \cdot 8$ & $8 \cdot 2$ \\
\hline Histidine & $3 \cdot 0$ & 3.8 & 3.8 & 3.4 \\
\hline Arginine & $8 \cdot 5$ & 5.0 & $8 \cdot 2$ & 5.6 \\
\hline Tryptophan & $1 \cdot 0$ & $2 \cdot 0$ & $2 \cdot 0$ & 1.5 \\
\hline
\end{tabular}

* Value for lysine based on present work. Remainder based on EAA : lysine ratio in calf carcasses (Williams, 1978).

$\dagger$ For details, see p. 311 .

\section{DISCUSSION}

There are practical and economic limitations to the estimation of the amino acid requirements of the preruminant calf. It is very expensive to produce a diet that is markedly limiting in one EAA and in which all (Tzeng, 1974) or almost all (Williams \& Smith, 1975; Foldager et al. 1977) of the amino acids are provided in crystalline form. It is cheaper to replace some of the milk protein with an alternative protein which is markedly deficient in one EAA to produce a diet which is palatable and does not result in digestive disturbances. A protein that satisfies these requirements is wheat gluten (Williams, I974) which has a very low lysine content and is readily digested. Its amino acids should therefore be absorbed at a similar rate to those of milk protein and to free amino acid supplements ensuring optimum utilization (Longenecker \& Hause, 1958; Rolls et al. 1972). This was confirmed in the present experiments where the maximum values for $\mathrm{N}$ retention $(0.43)$ and ADN $(0.97)$ were close to those reported for calves given cow's milk (Blaxter \& Wood, 1952; Porter \& Hill, 1962; Tzeng, I974).

The problem in experiments to determine amino acid requirements is to interpret the changes in some measure of response (e.g. weight gain, plasma urea) that occur when the amount of the limiting amino acid is varied. Arbitrarily, the observations may be divided into groups corresponding to treatments that are $(a)$ deficient and $(b)$ adequate. The dietary intake at the intersection of the straight lines fitted through these two groups of points is then taken as the requirement. This approach is exemplified in Fig. I. There are critics of this method, however (Hegsted, 1973). Even if the response in an individual calf is discontinuous the average response for a group of calves would be a curve. It follows that the requirement obtained will depend on the levels of the amino acid tested and on the subjective division of the observations into the two groups. It seemed more realistic to fit polynomial curves to the results. The lysine requirement was then assessed (subjectively) from the quadratic curves. The mean lysine requirement $(7.8 \mathrm{~g} / \mathrm{d})$ was the same for both methods although there were large differences between the methods for the lysine requirement based on plasma lysine and $\mathrm{N}$ retention responses. In our studies on the methionine requirements of the preruminant 
calf (Williams \& Smith, 1975) the responses of plasma methionine and PU to dietary methionine supplementation were used to estimate the requirement and no direct examination of responses in animal performance was made. Each of these methods of estimating amino acid requirements has been shown for other species (Zimmerman \& Scott, I965; Lewis \& Speer, 1973, 1975) and recently for the preruminant calf (Tzeng, 1974; Foldager et al. I977) to give a value which corresponds to an intake of the amino acid at which maximum $\mathrm{N}$ retention and growth are attained. This is confirmed in the present study although the value obtained from PU response is rather higher than the others. This is surprising since only Foldager et al. (1977) found that PU was quite insensitive for measuring methionine requirements.

The estimated lysine requirements in this study, $7.8 \mathrm{~g} / \mathrm{d}\left(0.43 \mathrm{~g} / \mathrm{kg}\right.$ body-weight (W) ${ }^{0.75}$ per d) for $50-58 \mathrm{~kg}$ calves growing at $0.25 \mathrm{~kg} / \mathrm{d}$, was much lower than the value, $12.6 \mathrm{~g} / \mathrm{d}$ $\left(0.78 \mathrm{~g} / \mathrm{kg} \mathrm{W}{ }^{0.75}\right.$ per d) reported by Foldager et al. (1977) for $43 \mathrm{~kg}$ calves growing at about the same rate. It is probable that this very high value was due to its having been calculated by the carcass analysis method using methionine as the reference amino acid. Since methionine is not only used for tissue synthesis but as a methyl donor and in the synthesis of S-containing compounds its use in the carcass analysis method should be avoided (Williams et al. I954). For example, the cystine intake in the studies of Foldager et al. (I977) represented about $25 \%$ of the total SAA requirements. No direct information is available for the calf, but in the pig it is assumed that cystine can contribute approximately half the SAA requirements (see Agricultural Research Council, 1967). If this is so, part of the methionine received by the calves must have been used to satisfy the cystine requirements. It is therefore difficult to define the methionine requirement in absolute terms and if this value was overestimated by Foldager et al. (1977) it would result in an over-estimate of the requirements for the other EAA.

The lysine requirement of $9.8 \mathrm{~g} / \mathrm{d}\left(0.57 \mathrm{~g} / \mathrm{kg} \mathrm{W} \mathrm{W}^{0.75}\right.$ per $\left.\mathrm{d}\right)$ reported by Tzeng (1974) for $50 \mathrm{~kg}$ calves growing at $0.7 \mathrm{~kg} / \mathrm{d}$ is consistent with that found in the present study considering the difference in growth rates. Patureau-Mirand et al. (1976) also found that the lysine requirement $\left(44.9 \mathrm{~g} / \mathrm{d}\right.$ or $\mathrm{I} \cdot \mathrm{I} 5 \mathrm{~g} / \mathrm{kg} \mathrm{W} \mathrm{W}^{0.75}$ per d) was higher for $150 \mathrm{~kg}$ calves growing at $\mathrm{I} \cdot 5 \mathrm{~kg} / \mathrm{d}$ than for $50-130 \mathrm{~kg}$ calves growing at $\mathrm{I} \cdot 0 \mathrm{~kg} / \mathrm{d}\left(34.9 \mathrm{~g} / \mathrm{d}\right.$ or $1 \cdot 30 \mathrm{~g} / \mathrm{kg} \mathrm{W}^{0.75}$ per d (Patureau-Mirand et al. (1973b)). It is probable that their very high values were related to the rapid growth of their calves but no significant improvements in growth rate were found with increasing lysine supplementation and more information to explain the apparent discrepancies is required.

Apart from the studies of Patureau-Mirand et al. (1974) and Foldager et al. (I977) there has been little work designed to study the requirements of the calf for EAA other than lysine or the SAA. The EAA requirements estimated by Patureau-Mirand et al. (1974) from the accumulation of amino acids in the blood of calves given dietary proteins of different amino acid composition are, except for arginine, between two to three times higher than those found in the present study. This again is probably due to the much higher growth rate of their calves. Except for histidine the EAA requirements estimated by Foldager et al. (1977) are from approximately one- to two-thirds higher than those found in the present study. This is probably, as in the instance of lysine, due to the use of methionine as the reference amino acid.

The histidine requirements were similar because the histidine content ( $14.7 \mathrm{~g} / \mathrm{kg}$ crude protein $(\mathrm{N} \times 6.25)$ (Jakobsen, 1957)) of the calf carcasses used in the calculations of Foldager et al. (1977) was much lower than that used in the present study $(24.6 \mathrm{~g} / \mathrm{kg}$ crude protein (Williams, 1978)). This highlights one of the criticisms of the carcass analysis procedure (Ericson, 1961). Whilst it is recognized that this procedure cannot give the most precise measure of amino acid requirements there is evidence for other species (Williams et al. 1954; 
Buraczewski, I973) that requirements for growth determined in this way agreed closely with those estimated by alternative procedures. Indeed some of the values for the rat estimated by Williams et al. (1954) are still incorporated in standard tables of nutrient requirements (Warner \& Breuer, I972). The alternative procedures themselves are not without their critics (Hegsted, 1976). Clearly the carcass analysis procedure estimates only the amino acid requirements for tissue protein synthesis and will therefore underestimate the requirements for those amino acids needed for other functions such as methionine, tryptophan, tyrosine, phenylalanine and arginine. For example the total SAA requirements estimated in the present study were $3.7 \mathrm{~g} / \mathrm{d}$ compared with the $4.5 \mathrm{~g} / \mathrm{d}$ estimated by alternative methods (Williams \& Smith, I975). This confirms that cow's milk, given at the same level of intake as the synthetic diet used in these experiments, would provide no surplus of SAA (Table 3 ). The information provided by the carcass analysis procedure is probably sufficiently precise to speculate that cow's milk should contain adequate amounts of the other EAA except for arginine (Table 3). This confirms the view of Robert (1971) who concluded that although the SAA might be limiting in cow's milk most of the other EAA appeared to be present in excess. The exception is arginine which, since cow's milk would provide only approximately $60 \%$ of the requirement estimated in the present study, must be synthesized by the calf. Arginine has been found to be synthesized in the tissues of the cow (Black et al. 1957) and the sheep (Downes, I96I). It is probable that the preruminant calf would only receive insufficient EAA when given diets in which milk protein is replaced by substantial amounts of alternative proteins. For example, an unsupplemented synthetic diet comparable to the cow's-milk diet in which isolated soya-bean protein (ISP) replaced milk protein would supply only $\mathrm{I} \cdot 3 \mathrm{~g}$ methionine and $\mathrm{I} \cdot 4 \mathrm{~g}$ cystine and would be markedly deficient in SAA and supplementation of such a diet with methionine was reported to improve $\mathrm{N}$ retention of calves (Porter \& Hill, 1964). If the ISP replaced only $50 \%$ of the milk protein it would probably contain adequate amounts of EAA (Table 3), but a corresponding wheat-gluten diet, apart from being severely deficient in lysine would be barely adequate in threonine and histidine. Support for the adequacy of cow's-milk diets is given by the many experiments in which supplementation with methionine or lysine or both have failed to improve animal performance (Odorico \& Brette, I968; Bakker, 1968; Van Hellemond \& Iwema, I97I; Patureau-Mirand et al. 1973). It is possible that the present estimates of the requirements of most of the EAA for the preruminant calf may be sufficiently precise for most circumstances (Patureau-Mirand et al. I $974 a, b$ ) particularly in view of the limited scope for dietary manipulation in the preruminant calf and the subsequent difficulties of estimating the requirements.

The authors thank Dr R. H. Smith for his helpful interest, Miss C. L. Phillips for supervising the care of the animals, Mr J. E. Cockburn for carrying out amino acid analyses and Miss S. Perry for technical assistance.

\section{REFERENCES}

Agricultural Research Council (1967). The Nutrient Requirements of Farm Livestock No. 3, Pigs. London: Agricultural Research Council.

Bakker, Y. Tj. (1968). Veet eeten Zuivelker. II, 548.

Barber, R. S., Braude, R., Mitchell, K. G. \& Myres, A. W. (1971). Br. J. Nutr. $25,285$.

Black, A. L., Kleiber, M., Smith, A. H. \& Stewart, D. N. (1957). Biochim. biophys. Acta $23,54$.

Blaxter, K. L. \& Wood, W. A. (I952). Br. J. Nutr. 6, I.

Bouchard, R. \& Brisson, G. J. (1974). J. Dairy Sci. 57, 640.

Brown, J. A. \& Cline, T. R. (1974). J. Nutr. 104, 542.

Buraczewski, S. (1973). Proc. Symp, on Amino Acids, Brno, Czeckoslovakia C, I.

Chi, M. S. \& Speers, G. M. (I977). Poult. Sci. 56, 52 I.

Cochran, W. G. \& Cox, G. M. (I957). Experimental Designs, and ed., p. 446. London and New York: John Wiley \& Sons.

Coombe, N. B. \& Smith, R. H. (1973). Br. J. Nutr. 30, 33 I. 
Downes, A. M. (1961). Aust. J. biol. Sci. 14, 254.

Ericson, L.-E. (196I). Acta physiol. Scand. 52, 90.

Foldager, J., Huber, J. T. \& Bergen, W. G. (1977). J. Dairy Sci. 6o, I095.

Hegsted, D. M. (1973). In Proteins in Human Nutrition, p. 275 [J. W. G. Porter and B. A. Rolls, editors]. London and New York: Academic Press.

Hegsted, D. M. (1976). J. Nutr. 106, 307.

Jakobsen, P. E. (1957). Beretn. Forsøgslab. no. 299.

Kirk, R. D. \& Walker, D. M. (1976a). Aust. J. agric. Res. 27, 109.

Kirk, R. D. \& Walker, D. M. (1976b). Aust. J. agric. Res. 27, I 7.

Lewis, A. J. \& Speer, V. C. (1973). J. Anim. Sci. 37, I04.

Lewis, A. J. \& Speer, V. C. (I975). J. Anim. Sci. 40, 892.

Longenecker, J. B. \& Hause, N. L. (1958). Nature, Lond. 182, 1739.

Mitchell, H. H. (1950). In Protein and Amino Acid Requirements of Mammals, p. I [A. A. Albanese, editor].

New York: Academic Press.

Odorico, G. \& Brette, A. (1968). Bull. Soc. Scient. Hyg. aliment. 56, 136.

Patureau-Mirand, P., Grizard, J., Prugnaud, J. \& Pion, R. (1976). Annls Biol. anim. Biochim. Biophys. 16, 579.

Patureau-Mirand, P., Prugnaud, J. \& Pion, R. (1973a). Annls Biol. anim. Biochim. Biophys. 13, 225.

Patureau-Mirand, P., Prugnaud, J. \& Pion, R. (1973b). Annls Biol. anim. Biochim. Biophys. 13, 683.

Patureau-Mirand, P., Toullec, R., Paruelle, J. L., Prugnaud, J. \& Pion, R. (1974). Annls Zootech. 23, 343.

Porter, J. W. G. \& Hill, W. B. (I 962). A. Rep. natn. Inst. Res. Dairy. p. 130.

Porter, J. W. G. \& Hill, W. B. (1964). A. Rep. natn. Inst. Res. Dairy. p. I 24.

Robert, J. C. (197I). Proc. int Milk Replacer Symp, Zurich, p. I 49.

Rolls, B. A., Porter, J. W. G. \& Westgarth, D. R. (I972). Br. J. Nutr. 28, 283.

Roy, J. H. B., Shillam, K. W. G., Hawkins, G. M. \& Lang, J. M. (1958). Br. J. Nutr. 12, 123.

Roy, J. H. B., Stobo, 1. J. F., Shotton, S. M., Ganderton, P. \& Gillies, C. M. (1977). Br. J. Nutr. 38, I67.

Smith, R. H. (1959). Biochem. J. 71, 306.

Smith, R. H. \& McAllan, A. B. (1970). Br. J. Nutr. 24, 545.

Tzeng, D. Y-M. (1974). Studies on the lysine and methionine requirements of the suckling calf. PhD Thesis, University of Illinois.

Van Hellemond, K. K. \& Iwema, S. (1971). Proc. Ioth int. Congr. Anim. Prod., Versailles.

Warner, R. G. \& Breuer, L. H. (1972). Nutrient Requirements of Domestic Animals no. 10, p. 56. Washington, DC: National Academy of Sciences.

Williams, A. P. (1974). Amino acid requirements of the young bovine. PhD Thesis, Reading University. Williams, A. P. (1978). J. agric. Sci., Camb. 90, 617.

Williams, H. H., Curtin, L. V., Abraham, J., Loosli, J. K. \& Maynard, L. A. (I954). J. biol. Chem. 208277. Williams, A. P. \& Smith, R. H. (1975). Br. J. Nutr. 33, 149.

Zimmerman, R. A. \& Scott, H. M. (1965). J. Nutr. 87, I3. 